\title{
Characterisation of Biogenic Amines in Fish Collected from Sarawak Using Gas Chromatography
}

\author{
MUHAMMAD ABDURRAHMAN MUNIR*, ZAINI ASSIM \& FASIHUDDIN AHMAD \\ Department of Chemistry, Faculty of Resource Science and Technology, Universiti Malaysia Sarawak, \\ 94300 Kota Samarahan, Sarawak, Malaysia \\ *Corresponding author: muhammadabdurrahman2220@gmail.com
}

\begin{abstract}
Determination of five biogenic amines (heptylamine, histamine, tyramine, cadaverine and spermidine) in fish was optimised and validated using gas chromatography - flame ionisation detector (GC-FID) followed by confirmation using mass spectrometry (MS). The biogenic amines were derivatised using BSA (N, O-bis (trimethylsilyl) acetamide) + TMCS (trimethylchlorosilane) as a derivatisation agent. The linear working range was between $0.9995-0.9999$. The limit of detection (LODs) were in the range of $1.20-2.90 \mu \mathrm{g} / \mathrm{mL}$. The efficiency of recovery for every biogenic amines, which ranged between $98.41-116.39 \%$, indicated that analytical procedure can be used to extract biogenic amines in fish. Using GC-FID, the concentration of five biogenic amines were simultaneously determined in fresh and salted fish samples such as mackerel (Scomberomorus guttatus), sardine (Sardinella gibbosa), whiptail (Himantura walga), gourami (Trichogaster pectoralis) and toli shad (Tenualosa toli). Histamine is found in fresh mackerel (S. guttatus) and sardine ( $S$. gibbosa) at concentration of 5.96 and $2.69 \mathrm{mg} / \mathrm{kg}$, respectively. Salted sardine (S. gibbosa) has histamine concentration of $8.95 \mathrm{mg} / \mathrm{kg}$. All histamine concentrations detected were below $50 \mathrm{mg} / \mathrm{kg}$ (FDA regulation) which is below the permissible threshold associated with scombroid poisoning. Cadaverine was detected in fresh sardine (S. gibbosa), whiptail stingray ( $H$. walga) and salted gourami ( $T$. pectoralis) with concentration of 4.96, 146.39 and $18.80 \mathrm{mg} / \mathrm{kg}$, respectively. None of them has biogenic amines, and histamine within FDA regulation levels (below $50 \mathrm{mg} / \mathrm{kg}$ ).
\end{abstract}

Keywords: Biogenic amines, fish, gas chromatography, limit of detection, recovery

\section{INTRODUCTION}

Biogenic amines are nitrogenous compounds which are usually low in molecular weight and have aliphatic, aromatic or heterocyclic chemical structures. Spermidine, cadaverine, putrescine and spermine are aliphatic structures whilst tyramine and phenythylamine are in aromatic form, and histamine and tryptamine are in the heterocylic structure (Kalac, 2009; Kim et al., 2009; Mohamed et al., 2009; Rabie \& Toliba, 2013). Furthermore, those which can be classified such as monoamines are tyramine and phenylethylamine, diamines are putrescine and cadaverine and polyamines for spermidine and spermine based on the number of amine groups (Spano et al., 2010). Biogenic amines can be found in food that contain protein such as fish, meat, cheese, vegetables and wines (Lorenzo et al., 2007). Biogenic amines can be shaped by means of amino acids decarboxylation which relies on the presence of a particular bacterial strain, or by amination and transamination of ketones and aldehydes (Rivas et al., 2008; Linares et al., 2011; Zhai et al., 2012). The factors that influence biogenic amines accumulation in food, are distribution and storage conditions, food physico-chemical parameters ( $\mathrm{pH}, \mathrm{NaCl}$ and ripening temperature), raw material quality, manufacturing processes, presence of decarboxylase-positive microorganisms and free amino acids and (PonsSanchez-Cascado et al., 2006; Linares et al., 2012).

Consumption of histamine by humans, especially at concentrations higher than 500 $\mathrm{mg} / \mathrm{kg}$, can lead to a serious issue of histamine poisoning (scombroid poisoining) (Gonzaga et al., 2009). The FDA has also determined, histamine concentration at below $50 \mathrm{mg} / \mathrm{kg}$ in fish could be consumed (FDA, 2011). Histamine is one of the amines implicated in the toxicity of food (Zaman et al., 2010), however at low levels histamine is not toxic; the presence of cadaverine and putrescine which have five times higher levels than histamine will contribute to histamine toxicity (Emborg \& Dalgaard, 2006). High concentrations of tyramine can cause intoxication. Cheese reaction with symptoms like histamine toxicity (Naila et al., 2010) can cause heart failure and brain 
haemorrhage (Standarova et al., 2008). The reaction between cadaverine, putrescine, spermidine and spermine with nitrite can lead to the synthesis of carcinogenic nitrosamines (Aflaki et al., 2015).

Analytical approaches for biogenic amines analysis are aimed to (1) modify the current methods or develop new methods; (2) determine the concentration of biogenic amines in products from other countries using valid methods; (3) analyse biogenic amines used to control the effectiveness of methods developed in food storage, food preparation and packaging to decrease production and accumulation of biogenic amines; and (4) understand the relation between the levels of biogenic amines and biogenic amine-producing microorganisms (Bedia, 2013). The reason for the detection of biogenic amines in food is to indicate food quality and potential toxicity (Onal, 2007).

Various analytical techniques have been employed to determine biogenic amines, such as, thin layer chromatography, high performance liquid chromatography, gas chromatography and capillary electrophoresis (CE) (Bricio et al., 2004; Awan et al., 2008; Tao et al., 2011; Aflaki et al., 2015). These involve the application of chemical reagents such as perchloric acid, trichloroacetic acid, hydrochloric acid and organic solvents for the purpose of extraction of amines from food and beverages (Karovicova \& Kohajdova, 2005; Jia et al., 2011; Sagratini et al., 2012; Lazaro et al., 2013).

Fish is an important protein source and also highly perishable. During the deterioration process in fish, bacterial decarboxylases catalyse will convert amino acids to biogenic amines. Biogenic amines concentration relies on the species of fish, temperature, degree of microbiological contamination and storage time. The time and temperature are the main factors for the biogenic amines formation during handling and storage of fresh fish. Bacteria which is associated with biogenic amines are similarly present in a saltwater environment. The formation of biogenic amines in fish such as sardine, tuna, herring and anchovies has been determined (FDA, 2011; Chong et al., 2014; Aflaki et al., 2015). Histamine fish poisoning known as scombroid poisoning is seafood toxicity related to the improper storage of fish. The term "scombroid" is derived from the family Scombridae such as, tuna and mackerel. Non- scombroid fish such as mahi-mahi (Coryphaena spp.), sardines (Sardinella spp.), herring (Clupea spp.) and swordfish (Xiphias gladius) are also able to cause scombroid poisoning in humans (Visciano et al., 2012).

\section{MATERIALS AND METHODS}

\section{Chemicals and Reagents}

Heptylamine, histamine, tyramine, cadaverine, spermidine and BSA+TMCS $(\mathrm{N}, \mathrm{O}-$ bis (trimethylsilyl) acetamide and trimethylchlorosilane) were purchased from Sigma-Aldrich. HPLC grade water, methanol and dichloromethane were acquired from the laboratory.

\section{Preparation of Standard Solutions}

Stock solution $(500 \mu \mathrm{g} / \mathrm{mL})$ of a mixture from heptylamine, histamine, tyramine, cadaverine and spermidine was prepared in HPLC grade water. The stock solution was derivatised and stored in the refrigerator. Standard solutions (25 - $150 \mu \mathrm{g} / \mathrm{mL}$ ), obtained by dilution of stock solution, were analysed by GC and calibration curves acquired.

\section{Fish and Fish Products}

Samples of fresh and salted fish such as sardine ( $S$. gibbosa), mackerel ( $S$. guttatus), gourami ( $T$. pectoralis), whiptail stingray ( $H$. walga) and toli shad (T. toli) were purchased from Riyal market, Kota Samarahan.

\section{The Procedure of Recovery Study and Derivatisation}

Recovery study was performed to validate the analytical procedure. Precisely $100 \mu \mathrm{g} / \mathrm{mL}$ of biogenic amines standard was spiked into $5 \mathrm{~g}$ of fish muscle and placed into an erlenmeyer flask containing methanol $50 \%(\mathrm{v} / \mathrm{v})$. The solution was homogenized by sonicator for twenty minutes and was placed in a $45^{\circ} \mathrm{C}$ water bath for 45 minutes. The extract was cooled to $30^{\circ} \mathrm{C}$ then filtered with filter paper into $20 \mathrm{~mL}$ vial. Exactly $200 \mu \mathrm{L}$ of the supernatant was put into vial $1 \mathrm{~mL}$ then derivatised. Precisely $200 \mu \mathrm{L}$ aliquot of a standard solution or sample in a vial was evaporated with nitrogen gas. $100 \mu \mathrm{L}$ BSA+TMCS was added into the vial and heated at $80^{\circ} \mathrm{C}$ for 20 minutes. After it had cooled, the derivatised solution was evaporated with nitrogen gas and the residue was re-dissolved in 
$100 \mu \mathrm{L}$ dichloromethane. $1 \mu \mathrm{L}$ of the supernatant was injected into GC.

\section{Gas Chromatography Flame Ion Detector and Mass Spectrometer}

This study uses two different detectors of gas chromatography: flame ionisation detector (FID) and mass spectrometer (MS). One of the GC validated was FID, whereas MS used to identify and confirm the structure of derivatised biogenic amines standard. GC-FID is an instrument that lacks the capability to confirm peak identity where it relies on the comparison between the retention time of standard used with the retention time of sample analysed. Thus, MS was applied in this study to ensure that the derivatise agent has bonded with the analyte, and it can be determined whether the derivatising procedure was a success or otherwise. Analysis of biogenic amines was optimised under similar temperature. The temperature programme was $110^{\circ} \mathrm{C}$ for 2 minutes and increased to $190^{\circ} \mathrm{C}$ at the rate of $5^{\circ} \mathrm{C} / \mathrm{min}$ maintained for 2 minutes. Derivatised biogenic amines were analysed using a GC, where a HP-5 phenyl methyl siloxane $(30 \mathrm{~m} \times 0.25 \mathrm{~mm} \times 0.25 \mu \mathrm{m})$ silica capillary column was installed in a Hewlett Packard 6890 and equipped with a FID. Carrier gas was hydrogen. Confirmation of peaks and retention times were obtained using GC-FID, derivatised biogenic amines were identified with GC-MS where it was performed on a capillary BPX-5 column (30 meter x $0.25 \mathrm{~mm}$ x $0.25 \mu \mathrm{m}$ ).

\section{RESULTS AND DISCUSSION}

\section{Method Validation}

Method validation was carried out by determining the specificity, linearity, LOD, LOQ, accuracy, precision and recovery. Results are listed in Table 1. Good specificity was obtained and can be seen in Figure 2, where only five derivatised biogenic amines appeared in
GC- FID chromatogram without impurities peaks and the identity of five peaks were confirmed using GC-MS. Linearity of the calibration curves was established by analysing five concentrations of a mixture of biogenic amines $(25-150 \mu \mathrm{g} / \mathrm{mL})$. Good linearity was acquired between peak area and concentration where the value was $R^{2}$ : 0.9995- 0.9999 .

LOD was ascertained from the lowest amine concentration required to give a signal to noise ratio of three ( $3 \mathrm{SD} / \mathrm{N})$, while LOQ was ascertained with a signal to noise ratio of ten (10 $\mathrm{SD} / \mathrm{N})$ (Gosetti et al., 2007). The precision and accuracy of the technique was evaluated by analysing six times the mixture of derivatised biogenic amines at $150 \mu \mathrm{g} / \mathrm{mL}$ on the same day (intra-assay). Good reproducibility was obtained where RSD (SD*100/mean) below 2\% were found (Table 1). A recovery study was performed to validate the analytical procedure, where a concentration at $100 \mu \mathrm{g} / \mathrm{mL}$ of a biogenic amines mixture solution was spiked into fish muscle. The solvent was methanol $50 \%(\mathrm{v} / \mathrm{v})$ whereas the derivatise agent was a mixture of BSA+TMCS. The recovery is estimated as $R=\left(\mathrm{C}_{\text {spiked }}-\mathrm{C}_{\text {sample }}\right)$ / $\mathrm{C}_{\text {added, }}$, where $\mathrm{C}_{\text {spiked }}$ is the level or amount in spiked sample and $\mathrm{C}_{\text {sample }}$ is the level or amount in the sample before to spike and $\mathrm{C}_{\text {added }}$ is the level or amount of enhanced standard. Satisfactory recovery for biogenic amines was obtained ranged between (98.41-116.39\%) (Table 1).

\section{Analysis of Fish and Fish Products}

Identification of peaks in samples was based on the comparison of retention time between the retention time of derivatised biogenic amines standard with the retention time of sample.

Table 2 shows that all fresh fish concentration contain biogenic amines. The levels of histamine, tyramine and spermidine were found in mackerel

Table 1. The values of linearity, LOD, LOQ, intra-assay and recovery studies.

\begin{tabular}{lccccc}
\hline Biogenic amine & $R^{2}$ & LOD $(\mu \mathrm{g} / \mathrm{mL})$ & LOQ $(\mu \mathrm{g} / \mathrm{mL})$ & $\begin{array}{c}\text { Intra-assay }(\% \mathrm{RSD}) \\
(\mathrm{n}=6)\end{array}$ & Recovery $(\%)$ \\
\hline Heptylamine & 0.9995 & 2.44 & 8.13 & 0.92 & 102.73 \\
Histamine & 0.9999 & 1.46 & 4.85 & 0.78 & 105.71 \\
Tyramine & 0.9999 & 2.90 & 9.65 & 2.01 & 98.41 \\
Cadaverine & 0.9998 & 2.03 & 6.77 & 1.36 & 109.09 \\
Spermidine & 0.9998 & 1.20 & 3.98 & 0.79 & 116.39 \\
\hline
\end{tabular}

$R^{2}$ : square of regression coefficient; LOD: limit of detection; LOQ: limit of quantification; RSD: relative standard deviation. 


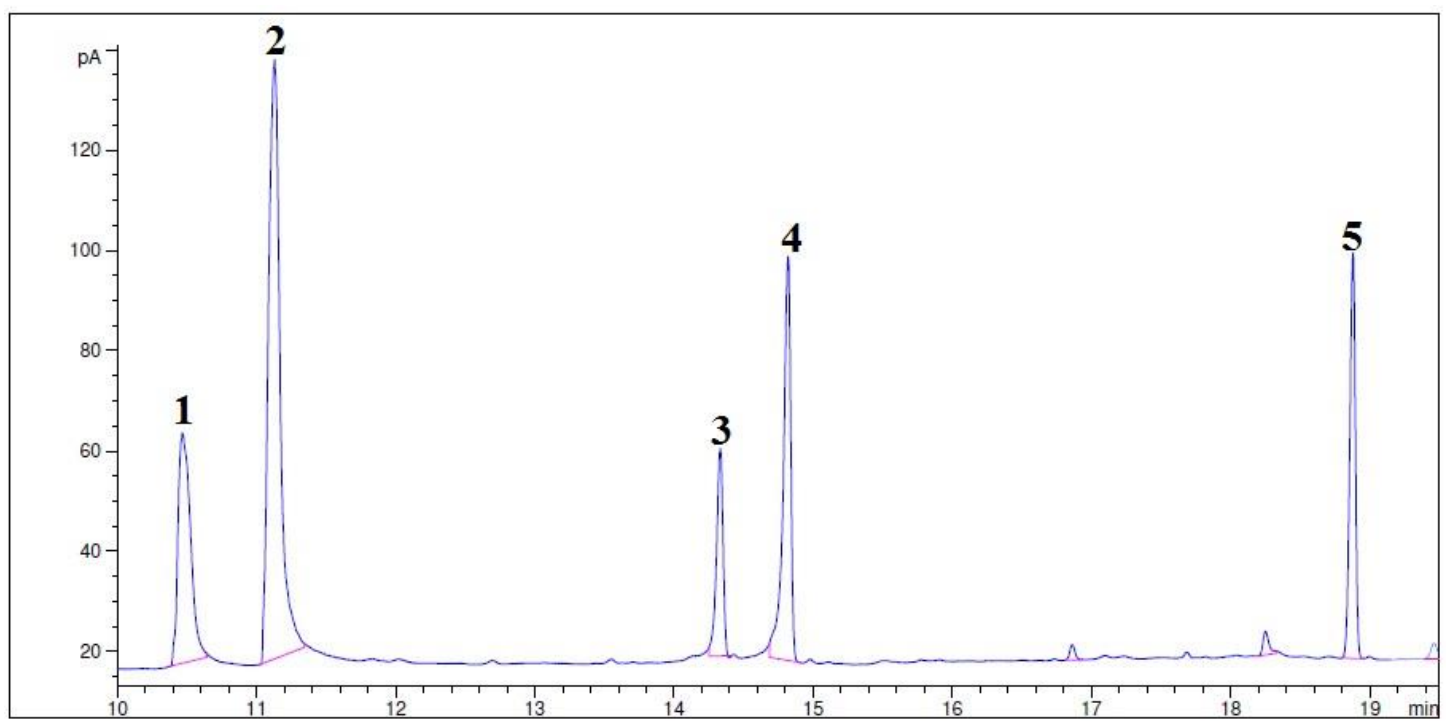

Figure 1. GC-FID chromatogram for concentration at $100 \mu \mathrm{g} / \mathrm{mL}$, (1) heptylamine - $10.45 \mathrm{~min}$, (2) histamine $11.12 \mathrm{~min}$, , (3) tyramine - $14.32 \mathrm{~min}$, (4) cadaverine - $14.88 \mathrm{~min}$ and (5) spermidine $-18.89 \mathrm{~min}$.

(S. guttatus) with concentration at 5.96, 103.29 and $7.38 \mathrm{mg} / \mathrm{kg}$, respectively. Sardine $(S$. gibbosa) contained the levels of heptylamine, histamine, tyramine, cadaverine and spermidine with concentration at $6.08,2.69,106.95,4.96$, $4.04 \mathrm{mg} / \mathrm{kg}$, respectively. Cadaverine and spermidine concentration were found in whiptail stingray $(H$. walga) at 146.39 and $6.18 \pm 0.24$ $\mathrm{mg} / \mathrm{kg}$, respectively; while gourami ( $T$. pectoralis) contained the levels of heptylamine, tyramine and spermidine with concentration at $15.11,135.24$ and $19.97 \mathrm{mg} / \mathrm{kg}$, respectively. Toli shad (T. toli) had only two biogenic amines such as, tyramine and spermidine, with concentration at $46.53 \pm 3.94$ and $11.30 \pm 0.76$ $\mathrm{mg} / \mathrm{kg}$, respectively.

According to Gonzaga et al. (2009), mackerel (S. japonicus peruanus) is a common fish that contain biogenic amines, particularly histamine, whereby the histamine concentration is at 86 $\mathrm{mg} / \mathrm{kg}$ and based on the FDA regulation, this fish cannot be consumed. Low levels of histamine are also found in mackerel ( $S$. guttatus) and sardine (Dussumieria acuta) where the concentration is at 15.8 and $12.6 \mathrm{mg} / \mathrm{kg}$, respectively (Aflaki et al., 2015). Significantly reduced levels of biogenic amines are found in salted fish where toli shad (T. toli), mackerel ( $S$. guttatus) and whiptail stingray (H. walga) only contained spermidine with concentration at 8.75 ,
19.08 and $45.49 \mathrm{mg} / \mathrm{kg}$, respectively. Sardine ( $S$. gibbosa) and gourami (T. pectoralis) only contained histamine and cadaverine with concentration at 8.95 and $18.80 \mathrm{mg} / \mathrm{kg}$, respectively. The reduction of biogenic amines level in salted fish samples has also shown the influence of salt as a preservative that can control the production of biogenic amines in food, particularly fish. Low level of biogenic amines was also detected by Saaid et al. (2009). Histamine, tyramine and spermidine were found in salted gourami with concentration at 3.5, 5.9 and $3.7 \mathrm{mg} / \mathrm{kg}$, respectively. Only histamine and spermidine were found in salted mackerel with concentration at 111.8 and $3.6 \mathrm{mg} / \mathrm{kg}$, respectively. Even though histamine concentration in salted mackerel was beyond the limit of FDA $(50 \mathrm{mg} / \mathrm{kg})$, without the presence of cadaverine and putrescine, the histamine toxicity in this sample can be neglected. Kose et al. (2012) detected histamine, cadaverine, tyramine and spermidine in mackerel with concentration at $1.9,1.4,3.7$ and $26.4 \mathrm{mg} / \mathrm{kg}$, respectively.

There is a distinction between fresh fish and salted fish samples, whereby the amine levels in each salted fish had been reduced owing to the preservative or salt. Preservatives is one of the methods that can be applied to control the production or accumulation of biogenic amines (Naila et al., 2010). Good quality fish must 
Table 2. Biogenic amines concentration in fish and fish products $(n=6)$.

\begin{tabular}{|c|c|c|c|c|c|c|}
\hline \multirow{2}{*}{ No. } & \multirow{2}{*}{ Sample type } & \multicolumn{5}{|c|}{ Concentration of biogenic amines (mg/kg) } \\
\hline & & HEP & HIS & TYR & CAD & SPD \\
\hline \multicolumn{7}{|c|}{ Fresh Fish } \\
\hline 1 & Mackerel (S. guttatus) & n.d. & $5.96 \pm 0.72$ & $103.29 \pm 4.8$ & n.d. & $7.38 \pm 0.75$ \\
\hline 2 & Sardine (S. gibbosa) & $6.08 \pm 0.22$ & $2.69 \pm 0.75$ & $106.95 \pm 1.9$ & $4.96 \pm 0.26$ & $4.04 \pm 0.28$ \\
\hline 3 & Whiptail stingray (H. walga) & n.d. & n.d. & n.d. & $146.39 \pm 3.0$ & $6.18 \pm 0.24$ \\
\hline 4 & Toli shad (T. toli) & n.d. & n.d. & $46.53 \pm 3.94$ & n.d. & $11.30 \pm 0.76$ \\
\hline 5 & Gourami (T. pectoralis) & $15.11 \pm 0.38$ & n.d. & $135.24 \pm 6.8$ & n.d. & $19.97 \pm 1.70$ \\
\hline \multicolumn{7}{|c|}{ Salted Fish } \\
\hline 6 & Mackerel (S. guttatus) & n.d. & n.d. & n.d. & n.d. & $19.08 \pm 0.28$ \\
\hline 7 & Sardine $(S$. gibbosa $)$ & n.d. & $8.95 \pm 0.38$ & n.d. & n.d. & n.d. \\
\hline 8 & Whiptail stingray (H. walga) & n.d. & n.d. & n.d. & n.d. & $45.29 \pm 1.11$ \\
\hline 9 & Toli shad (T. toli) & n.d. & n.d. & n.d. & n.d. & $8.75 \pm 0.34$ \\
\hline 10 & Gourami (T. pectoralis) & n.d. & n.d. & n.d. & $18.80 \pm 0.97$ & n.d. \\
\hline
\end{tabular}

n.d.: non-detected; HEP: heptylamine; HIS: histamine; TYR: tyramine; CAD: cadaverine; SPD: spermidine.

contain less than $10 \mathrm{mg} / \mathrm{kg}$ of histamine, $30-50$ $\mathrm{mg} / \mathrm{kg}$ can be considered as decomposition (Oguri et al., 2007). Consuming $40 \mathrm{mg}$ biogenic amines or more per meal is considered toxic for human. Not all biogenic amines are toxic, yet the levels of histamine and tyramine must be considered (Saaid et al., 2009).

The FDA has suggested histamine content of fish should be $<50 \mathrm{mg} / \mathrm{kg}$ and considered safe for human consumption, $50-1000 \mathrm{mg} / \mathrm{kg}$ is probably toxic and $>1000 \mathrm{mg} / \mathrm{kg}$ is considered toxic and not safe for consumption (Proestos et al., 2008). Tyramine level $100-800 \mathrm{mg} / \mathrm{kg}$ is admissible but over $800 \mathrm{mg} / \mathrm{kg}$ is considered poisonous (Saaid et al., 2009).

\section{CONCLUSION}

All samples such as fresh and salted fish have biogenic amines, salting is one of the factors which can influence or control the biogenic amines level in fish. Although there are no reports yet on cases involving such poisoning, it is recommended to moderate consumption of fish containing biogenic amines exceeding levels set by the FDA. It can be concluded methanol $50 \%(\mathrm{v} / \mathrm{v})$ may be used as a solvent to extract biogenic amines from food, particularly fish. Also a mixture of BSA + TMCS can be applied as a derivatise agent. Good validation method such as specificity, linearity, LOQ, precision and accuracy has showed that column (capillary HP5) and temperature programme employed in GCFID can be used. Furthermore, GC-MC (capillary BPX-5 column) can also be applied to identify the structure of derivatised biogenic amines.

\section{ACKNOWLEDGEMENT}

The authors would like to acknowledge Faculty of Resource Science and Technology (FRST), UNIMAS for the use of research facilities at Department of Chemistry, FRST, UNIMAS.

\section{REFERENCES}

Aflaki, F., Ghoulipour, V., Saemian, N., Sheibani, S., \& Salahinejad, M. (2015). Determination of biogenic amines in Persian gulf fish: application of stirrer bead milling extraction method. Food Measure, 9: 86-94.

Awan, M.A., Fleet, I., \& Thomas, C.L.P. (2008). Determination of biogenic diamines with vaporisation derivatization approach using solidphase microextraction gas chromatography-mass spectrometry. Food Chemistry, 111(2): 462-468.

Bedia, E.F. (2013). Recent analytical approaches to analysis of biogenic amines in food samples. Trends in Analytical Chemistry, 52: 239-247.

Bricio, B.M.S., Rios, A., \& Valcarcel, M. (2004). Direct automatic determination of biogenic amines in wine by flow injection-capillary electrophoresis-mass spectrometry. Electrophoresis, 25: 3427-3433.

Chong, C.W., Abu Baker, F., Rahman, R.A., Bakar, J., \& Zaman, M.Z. (2014). Biogenic amines, amino acids and microflora changes in Indian mackerel (Rastrellinger kanagurta) stored at ambient $\left(25-29^{\circ} \mathrm{C}\right)$ and ice temperature $\left(0^{\circ} \mathrm{C}\right)$. Journal Food and Science Technology, 51: 11181125 . 
Emborg, J. \& Dalgaard, P. (2006). Formation of histamine and biogenic amines in cold-smoked tuna: an investigation of psychrotolerant bacteria from samples implicated in cases of histamine fish poisoning. Journal of Food Protein, 69: 897-906.

Food and Drug Administration (FDA). (2011). Fish and fishery products hazards and control guidance. Fourth Edition. Washington DC: Department of Health and Human Services, FDA, Center for Food Safety and Applied Nutrition.

Gonzaga, V.E., Lescano, A.G., Huaman, A.A., Salmn-Mulanovich, G., \& Blazes, D.L. (2009). Histamine levels in fish from markets in Lima, Peru. Journal of Food Protein, 72: 1112-1115.

Gosetti, F., Mazzucco, E., Gianotti, V., Polati, S., \& Gennaro, M.C. (2007). High-performance liquid chromatography/tandem mass spectrometry determination of biogenic amines in typical Piedmont cheeses. Journal of Chromatography A, 1149: 151-157.

Jia, S., Kang, Y.P., Park, J.H., Lee, J., \& Kwon, S.W. (2011). Simultaneous determination of 23 amino acids and 7 biogenic amines in fermented food samples by liquid chromatography/quadrupole time of flight mass spectrometry. Journal of Chromatography A, 1218(51): 9174-9182.

Kalac, P. (2009). Recent advanced in the research on biological roles of dietary polyamines in man. Journal of Application Biomedical, 7(2): 65-74.

Karovicova, J. \& Kohajdova, Z. (2005). Biogenic amines in food. Chemical Papers, 59(1): 70-79.

Kim, M.K., Mah, J.H., \& Hwang, H.J. (2009). Biogenic amine formation and bacterial contribution in fish, squid and shellfish. Food Chemistry, 116(1): 87-95.

Lazaro, C.A., Conte-Junior, C.A., Cunha, F.L., Marsico, E.T., Mano, S.B., \& Franco, R.M. (2013). Validation of an HPLC methodology for the identification and quantification of biogenic amines in chicken meat. Food Analytical Methods, 6: 1024-1032.

Linares, D.M., Rio, D.B., Ladero, V., Martinez, N., Fernandez, M., \& Martin, M.C. (2012). Factors influencing biogenic amines accumulation in dairy products. Frontiers in Microbiology, 3: 180190.

Linares, D.M., Martin, M., Ladero, V., Alvarez, M.A., \& Fernandez, M. (2011). Biogenic amines in dairy products. Critical Reviews in Food Science and Nutrition, 51(7): 691-703.

Lorenzo, J.M., Martinez, S., Franco, I., \& Carballo, J. (2007). Biogenic amine content during the manufacture of dry-cured bacon, a Spanish traditional meat product: effect of some additives. Meat Science, 77(2): 287-293.
Mohamed, R., Livia, S.S., Hassan, S., Soher, E.S., \& Ahmed-Adel, E.B. (2009). Changes in free amino acids and biogenic amines of Egyptian saltedfermented fish (Feseekh) during ripening and storage. Food Chemistry, 115.

Naila, A., Flint, S., Fletcher, G., Bremer, P., \& Meerdink, G. (2010). Control of biogenic amines in food-existing and emerging approaches. Journal of Food Science, 75: 139-150.

Oguri, S., Enami, M., \& Soga, N. (2007). Selective analysis of histamine in food by means of solidphase extraction cleanup and chromatographic separation. Journal of Chromatography, 1139: 7074.

Onal, A. (2007). A review: current analytical methods for the determination of biogenic amines in foods. Food Chemistry, 103(4): 1475-1486.

Pons-Sanchez-Cascado, S., Vesciana-Nogues, M., Bover-Cid, S., Marine-Font, A., \& Vidal-Carau, M. (2006). Use of volatile and non-volatile amines to evaluate the freshness of anchovies stored in ice. Journal of Science and Food Agriculture, 86(5): 699-705.

Proestos, C., Loukatos, P., \& Komaitis, M. (2008). Determination of biogenic amines in wines by HPLC with precolumn dansylation and fluorimetric detection. Food Chemistry, 106: 1218-1224.

Rabie, M. \& Toliba, A. (2013). Effect of irradiation and storage on biogenic amine content in ripened Egyptian smoked cooked sausage. Journal of Food and Science Technology, 50(6): 1165-1171.

Rivas, B., Goncalez, R., Landete, J.M., \& Munoz, R. (2008). Characterization of a second ornithine deacarboxylase isolated from Morganell morganii. Journal of Food Protein, 71(3): 657661.

Saaid, M., Saad, B., Hashim, N.H., Ali, A.S.M., \& Saleh, M.I. (2009). Determination of biogenic amines in selected Malaysian food. Food Chemistry, 113(4): 1356-1362.

Sagratini, G., Fernandez-Frazon, M., Berardinis, F., Font, G., Vittori, S., \& Manes, J. (2012). Simultaneous determination of eight underivatised biogenic amines in fih by solid phase extraction and liquid chromatography-tandem mass spectrometry. Food Chemistry, 132(1): 537-543.

Spano, G., Russo, P., Lonvaud-Funel, A., Lucas, P., Alexandre, H., Grandvalet, C., Coton, E., Coton, M., Barnavon, L., Bach, B., Rattray, F., Bunte, A., Magni, C., Ladero, V., Alvarez, M., Fernandez, M., Lopez, P., Corbi, A., Trip, H., \& Lolkema, J.S. (2010). Biogenic amines in fermented foods. European Journal of Clinical Nutrition, 64(3): 95100. 
Standarova, E., Borkovcova, I., \& Vorlova, L. (2008). The occurrence of biogenic amines in dairy products on the Czech market. Acta Scientiarium Poloranum Medicina Veterinaria, 7(4): 35-42.

Tao, Z., Sato, M., Han. Y., Tan. Z., Yamaguchi, T., \& Nakano, T. (2011). A simple and rapid method for histamine analysis in fish and fishery products by TLC determination. Food Control, 22: 11541157.

Visciano, P., Schirone, M., Tolafo, R., \& Suzzi, G. (2012). Biogenic amines in raw and processed seafood. Frontiers in Microbiology, 3: 188-190.
Zaman, M.Z., Abu Bakar, F., Selamat, J., \& Bakar, J. (2010). Occurrence of biogenic amines and amines degrading bacteria in fish sauce. Czech Journal of Food Science, 28: 440-449.

Zhai, H., Yang, X., Li., Xia, G. Cen, J., Huang, H., \& Hao, S. (2012). Biogenic amines in commercial fish and fish products sold in southern China. Food Control, 25: 303-330. 